\section{Serum fibronectin and C-reactive protein in prediction of preterm delivery}

DOI: 10.1515/rrlm-2015-0033

\section{To the Editor:}

Premature birth $(\mathrm{PB})$ represents the main cause of perinatal mortality and morbidity worldwide $(1,2)$. The proinflammatory cytokines became of interest for obstetricians in the context of theories referring to inflammation or intrauterine infections (IAI), which can lead to premature labor. An increased cytokines level induces elevations in the C-reactive protein (CRP) level, a liver protein synthesized soon after tissue damage or in case of infections (3). Medical research studies on PB included maternal CRP on the list of biomarkers used for sustaining the diagnosis of chorioamniotitis, especially in pregnant women presenting preterm rupture of chorioamniotic membranes (PROM). In other studies, CRP levels exceeding $7 \mathrm{mg} / 1$ are associated with an increased risk of $\mathrm{PB}$ in pregnant women with intact membranes $(2,4)$.

Fibronectin (FN) is a ubiquitous glycoprotein present in the extracellular matrix, exhibiting an important role in embryogenesis: being produced by trophoblasts it acts as a real "glue" and ensures the adhesion of the placenta to the decidua. Fetal fibronectin (fFN) in the cervicovaginal fluid has been intensely studied, having a high accuracy in prediction of spontaneous PB during the following 7-10 days (5).

The purpose of this study was to determine if the maternal serum FN and CRP levels in women with imminence of preterm labor are useful tools for prediction and diagnosis of PB.

The study was performed between January 2012 and December 2013. We included in this case-control study 92 patients presenting monofetal 22-34 weeks pregnancy, admitted to the Obstetrics-Gynecology Clinic of the Emergency County Hospital in Tîrgu-Mureş: a group of 52 pregnant women with imminent preterm symptoms and a control group of 40 asymptomatic pregnant women who came for a prenatal visit.

From the multitude of biomarkers which predict $\mathrm{PB}$, in our study we chose fibronectin because it was the most efficient biomarker. Based on the proteinaceous nature of fibronectin and theories that consider even subclinical IAI triggers of $\mathrm{PB}$, we associated the study of FN with the study of CRP. We developed a model for the determination of these biomarkers in maternal serum, for pregnant women between 2234 weeks. It included maternal serum sampling collected along with routine laboratory analysis, which is more easily performed, compared to the invasive investigations: amniocentesis or fetal sampling.

Blood samples were collected from the study group when they were admitted to the hospital and in case of the control group, when they came for the prenatal visit. The dosage of these biomarkers was performed once for all the patients. The average gestational age was $28.55 \pm 4.12$ weeks (study group) and $30.33 \pm 3.58$ weeks (control group), while the maternal age was: $28.67 \pm 6.74$ years for the study group and $30.63 \pm 4.88$ years in the control group.

We obtained demographic, obstetric and medical history of the pregnant women based on the data of a questionnaire attached to the informed consent document.*

The novelty of our study consisted in determining serum fibronectin using the IBL-International GMBH kit; the recommended reference range for adults being $24-124 \mu \mathrm{g} / \mathrm{ml}$. 
Statistical analysis was performed using GraphPad InStat3. Data were considered as nominal or quantitative variables. A chi-square test was used in order to compare the frequencies of nominal variables. Quantitative variables were compared using t, Mann-Whitney, ANOVA or Kruskal-Wallis tests, when appropriate. Based on the cut-off points, performance parameters of diagnostic validity were estimated and ROC curves were determined. The level of statistical significance was set at $\mathrm{p}<0.05$.

Of the 92 22-34 weeks pregnant women who met the study inclusion criteria, 52 patients were hospitalized with a diagnosis of imminent preterm birth $(56.52 \%)$ and 40 patients had a normal progression of pregnancy (43.47\%). Based on overall analysis of the pregnant women and studying the medical documentation, we found that 18 patients presented $\mathrm{PB} \leq 7$ days of being admitted to the hospital. A number of 34 patients gave birth over this interval and they were included in the subgroup with $\mathrm{PB} \geq 7$ days.

Statistical analysis showed that the mean level of serum fibronectin in the control group was $302.5 \pm 86.32 \mu \mathrm{g} / \mathrm{ml}$ with a significant difference compared to the control group $p<0.05$. Serum fibronectin levels were significantly higher in the subgroup of patients with $\mathrm{PB} \leq 7$ days of hospitalization (Table I).

Mann Whitney test showed significantly higher CRP levels $(p<0.01)$ in the group of pregnant women with imminence of $\mathrm{PB}$ versus control group, with the median value $2.49 \mathrm{mg} / 1$ (1.01-13.1). Application of Kruskall-Wallis test for both groups showed significantly increased serum CRP levels in pregnant women with PB $\leq 7$ days (Table I).

The $\mathrm{Chi}^{2}$ test showed that $58.2 \%$ of the pregnant women in the study group were women with multiple births, while in the subgroup with $\mathrm{PB} \leq 7$ days the majority of women were nulliparous $(80.6 \%)$. Our study has shown that PROM

Table I. Performance of noninvasive tests for diagnose preterm birth risk

\begin{tabular}{lcccc}
\hline \multirow{2}{*}{ Variables } & \multicolumn{2}{c}{ Study Group } & \multicolumn{2}{c}{ PB $\leq 7$ days } \\
\cline { 2 - 5 } & FN tests & CRP tests & FN tests & CRP tests \\
\hline $\begin{array}{l}\text { Biomarkers values } \\
\text { (mean } \pm \text { SD) } \\
\text { (median value) }\end{array}$ & $332.2 \pm 65.63 \mu \mathrm{g} / \mathrm{ml}$ & $5.18 \mathrm{mg} / 1$ & $360.6 \pm 45.30 \mu \mathrm{g} / \mathrm{ml}$ & $10.98 \mathrm{mg} / 1$ \\
\hline AUC & & $(0.74-169.4)$ & & $(2.43-169.4)$ \\
(area under ROC curve) & 0.59 & 0.68 & 0.70 & 0.85 \\
\hline p value & & & & \\
\hline Cut-off value & 0.10 & 0.0059 & 0.0044 & 0.0001 \\
\hline Sensitivity & $318.12 \mu \mathrm{g} / \mathrm{ml}$ & $2.56 \mathrm{mg} / 1$ & $365.32 \mu \mathrm{g} / \mathrm{ml}$ & $5.2 \mathrm{mg} / 1$ \\
(IC 95\%) & $73.8 \%$ & $76 \%$ & $61 \%$ & $77.78 \%$ \\
\hline Specificity & $59-84.4$ & $61.8-86.9$ & $35.7-82.7$ & $52.4-93.6$ \\
(IC 95\%) & $45 \%$ & $56.52 \%$ & $75 \%$ & $78.26 \%$ \\
\hline Positive Predictive Value & $29.3-61.5$ & $34.5-76.8$ & $58.8-87.3$ & $56.3-92.5$ \\
(PPV) (IC 95\%) & $63.3 \%$ & $79.2 \%$ & $52.2 \%$ & $73.7 \%$ \\
\hline Negative Predictive Value & $49.8-75.5$ & $65.0-89.5$ & $29.8-74.3$ & $48.8-90.9$ \\
(NPV) (IC 95\%) & $56.3 \%$ & $52 \%$ & $81.1 \%$ & $81.8 \%$ \\
\hline LR+ & $37.7-73.6$ & $31.3-72.2$ & $64.8-92.0$ & $59.1-95.0$ \\
(IC 95\%) & 1.33 & 1.75 & 2.44 & 3.58 \\
\hline LR - & $0.9-1.9$ & $1.2-2.6$ & $1.6-3.7$ & $2.6-5.0$ \\
(IC 95\%) & 0.6 & 0.42 & 0.52 & 0.28 \\
& $0.4-1.1$ & $0.2-0.8$ & $0.2-1.1$ & $0.09-0.9$ \\
\hline
\end{tabular}


was present in $11.10 \%$ of cases with symptoms and $\mathrm{PB} \leq 7$ days. Complications in the $\mathrm{PB} \leq 7$ days group were: PROM 19\%, genitourinary infections $17 \%$, arterial hypertensions (HTN) $11 \%$, diabetes mellitus (DM) 5\%, placenta praevia 5\% and others $25 \%$.

In our study we calculated performance parameters for the studied biomarkers by referring to the presence of labor in the study group versus the control group. Statistical analysis of the study group has shown that the sensitivity, specificity and PPV of CRP are higher than that of FN (Table I); these values indicate that both proteins are useful tools for predicting PB. NPV for both biomarkers were similar: $81.1 \%$ FN / 81.8\% CRP. To assess the ability of these biomarker tests to predict PB, ROC curves for the study group and the subgroup $\leq 7$ days were plotted and compared (Table I). The highest recorded FN level was $399.52 \mu \mathrm{g} / \mathrm{ml}: 27.78 \% \mathrm{Sn}, 97.50 \%$ Sp, LR(+)11.11, LR(-)0.74, while the highest CRP level was $11.63 \mathrm{mg} / 1,50 \% \mathrm{Sn}, 95.65 \% \mathrm{Sp}$, LR(+)11.50, LR(-)0.52.

Ideal biomarkers for PB should meet several conditions: to be biologically plausible, to have high sensitivity and specificity, to be associated with a progressive clinical parameter (preterm labor), to be determined by a reliable and reproducible method (6). Correct diagnosis of premature labor is important, early differentiation between true and false labor determining the management of PB. A meta-analysis which tested over 30 novel biomarkers led to the prediction accuracy of PB in asymptomatic pregnant women. Their conclusion was that none of the studied biomarkers met the criteria in order to be considered clinically useful in predicting $\mathrm{PB}$ due to the heterogeneity of the included studies. fFN in cervico-vaginal fluid has been most strongly associated with spontaneous $\mathrm{PB}$ and has the best accuracy in predicting PB within the following 7-10 days (7).
Most authors considered fFN as the gold standard for predicting preterm delivery; fFN measured using the ELISA technique is considered positive above $50 \mathrm{ng} / \mathrm{ml}$. A previous study described the following fFN test's range of performance: $97-98 \% \mathrm{Sn}, 70-97 \% \mathrm{Sp}$, PPV 74-93\% and NPV 98-100 \% (5). Unfortunately, a poor PPV makes fFN look more like a bronze standard (9). Several prior studies indicated the absence of a non-invasive gold standard for PROM diagnosis, leading to the need of identifying biomarkers that could be associated to this diagnosis (9).

Several authors indicate that CRP is pathological in pregnancy if it's level is between 7 and $20 \mathrm{mg} / \mathrm{l}$. In the absence of specific symptoms chorioamniotitis is difficult to be identified, but the majority of patients are diagnosed after delivery $(2,4)$. Spontaneous PROM is present in $8-10 \%$ of term births and $30-35 \%$ of $\mathrm{PB}$ are triggered by PROM. The cause-effect interrelation between PROM and IAI in PB remains constant in the opinion of most authors (10).

Our study indicated high sensitivity $(76 \%)$ and PPV (79.2\%), with moderate specificity (56.52\%) for CRP, indicating significant diagnostic value for this inflammatory marker in PB. However, our study had some limitations including a small sample size and a large range of gestational age.

Pregnant women with $\mathrm{PB} \leq 7$ days presented elevated CRP levels (10.98.mg/l) and PROM in $11.10 \%$ of cases. Although most pregnant women with PB had intact membranes, the elevated CRP in this group indicated the possibility of subclinical infections. Pregnancy complications for this subgroup confirmed data in the literature and the hypothesis that IAI are potential triggers of PB.

Other authors have studied several biomarkers but they indicated fFN as having the highest predictive value, followed by CRP tests with average levels of $7.99 \pm 3.56 \mathrm{mg} / 1$ in term births versus $18.13 \pm 9.13 \mathrm{mg} / \mathrm{l}$ in $\mathrm{PB}(3)$. 
In our study population the assessment of FN performance parameters showed high sensitivity $(73.8 \%)$ and moderate specificity (45\%), but sufficient for assessing the risk of PB. In the subgroup with $\mathrm{PB} \leq 7$ days, elevated $\mathrm{FN}$ levels were associated with an increased risk of PB. Thus if the level of serum FN is $365.32 \mu \mathrm{g} / \mathrm{ml}$, the $\mathrm{LR}(+)$ is 2.44 , the FN level of $399.52 \mu \mathrm{g} / \mathrm{ml}$ indicating that pregnant women have an 11.11 times higher risk of giving birth prematurely than the control group.

Serum FN and CRP determinations help us in the selection of real premature labor and enable the implementation of appropriate diagnostic and therapeutic behavior.

This study provided new information, suggesting that elevated maternal serum $\mathrm{FN}$ and CRP are associated with a high risk of PB. The results obtained in our study are encouraging, serum FN derived from pregnant women with symptoms of $\mathrm{PB}$ being a useful marker, with PPV (52.2\%) and high NPV (81.1\%), comparable with $\mathrm{fFN}$ in the prediction of $\mathrm{PB} \leq 7$ days.

\section{Cosmina Cristina Uzun', S. Voidăzan², Nemes-Nagy Enikő', V. Balogh- Sămărghițan' ${ }^{1}$ Fazakas Zita' ${ }^{1}$ B.P.Uzun ${ }^{3}$, B. Szabó $^{4}$}

${ }^{1}$ University of Medicine and Pharmacy, Tg-Mureş, Department of Medical Biochemistry,

${ }^{2}$ University of Medicine and Pharmacy, Tg-Mureş, Department of Epidemiology,

${ }^{3}$ Clinical County Hospital, Tg-Mureş, Clinic of Urology,

${ }^{4}$ University of Medicine and Pharmacy, Emergency Clinical County Hospital, Tg-Mureş, Department of Obstetrics and Gynecology

* Corresponding author: Septimiu Voidăzan, email: voidazan.septimiu@umftgm.ro

The study was approved by the Ethics Committee of the University of Medicine and Pharmacy in Tîrgu-Mureș; all patients eligible for the proposed trial completed the informed consent document, according to the Helsinki Declaration of the World Medical Association in 2013 on research performed on human subjects.

\section{Acknowledgement}

The study was partially supported by the Doctoral School of University of Medicine and Pharmacy, Tg-Mureş (enzimatic fibronectin kit).

We are grateful to the staff of the Clinical Laboratory of Emergency Clinical County Hospital, Tîrgu Mureş and to the staff of SC Dentanet Lab SRL .

\section{Conflict of interest}

The authors declare that there are no conflicts of interest.

Received: 19 $9^{\text {th }}$ December 2014; Accepted: $12^{\text {th }} \mathrm{Au}$ gust 2015; Published: 14 ${ }^{\text {th }}$ September 2015

\section{References}

1. World Health Organization. Born too soon, The Global Action Report on Preterm Birth, Geneva, 2012, 1-33, http://www.who.int/ 201204 borntoosoon-report.pdf.

2. Marinescu B. Conduita în naşterea prematură (Management of premature birth). In Dorina Codreanu, Seria Ghiduri Clinice pentru Obstetrică şi Ginecologie, Ghidul 10. Oscar Print, Bucureşti. 2011, 1-47.

3. Rezaei M, Shahgheibi S, Shahoei R, Zadvakili F, Farhadifar F, Noori $\mathrm{N}$ et al, Cervicovaginal Biomarkers and C-reactive Protein Levels in Preterm and Term Labor, Life Sci J, 2013, 10(6s):368-371.

4. Cunningham G, Leveno KJ, Bloom SL, Hauth JC, Rouse DJ, Spong CY. Pretem birth. In Twickler DM, Wendel GD. Williams Obstetrics 23rd Edition. Mc Graw Hil Medical, USA. 2010, 804-32.

5. Di Renzo GC, Roura LC, Facchinetti F, Antsaklis A, Breborowicz G, Gratacos E et al. Guidelines for the management of spontaneous preterm labor: identification of spontaneous preterm labor, diagnosis of preterm premature rupture of membranes, and preventive tools for preterm birth. J Matern Fetal Neonatal Med. May 2011;24(5):659-67. DOI: 10.3109/14767058.2011.553694 
6. Ristescu I, Grigoraş I, Biomarkers in early diagnosis of sepsis, Jurnalul de Chirurgie Iaşi, 2012, vol 8(2), 131140

7. Conde-Agudelo A, Papageorghiou, Kennedy SH, Villar J. Novel biomarkers for the prediction of the spontaneous preterm birth phenotype: a systematic review and meta-analysis. BJOG 2011;118:1042-54. DOI: 10.1111/j.1471-0528.2011.02923.x

8. London S. New test eyed for ruling out preterm delivery. Ob Gyn News. September 2011,28-29.

9. Rahkonen L. Preterm delivery and selected biomark- ers-phosphorylated insulin-like growth factor-binding protein-1 and matrix metalloproteinase-8-in cervical fluid. http://ethesis:helsinki.fi, Helsinky University Print, Helsinki 2010, 39-49.

10. Sorokin Y, Romero R, Mele L, Wapner RJ, Iams J, Dudley DJ, et al. Maternal serum interleukin-6, C-reactive protein and matrix metalloproteinase- 9 concentrations as risk factors for preterm birth $<32$ weeks and adverse neonatal outcomes. Am J Perinatol. 2010 September,27(8):631-40. DOI: 10.1055/s-0030-1249366. 